\title{
Assessment Physiological Cost of Selected Carpentry Tasks
}

\author{
Madhuri Kulkarni* and Priyanka Khakare \\ Department of Resource Management and Consumer Science, College of Community Science, \\ VNMKV, Parbhani (M.S.), India \\ *Corresponding author
}

\section{A B S T R A C T}

\begin{tabular}{|l|}
\hline Key w or d s \\
Physiological cost, \\
$\begin{array}{l}\text { Carpentry tasks, } \\
\text { Posture, Carpenter }\end{array}$ \\
\hline Article Info \\
\hline $\begin{array}{l}\text { Accepted: } \\
\text { 18 December } 2020 \\
\text { Available Online: } \\
\text { 10 January 2021 }\end{array}$ \\
\hline
\end{tabular}

\begin{abstract}
The study entitled "Assessment of Physiological Cost of Selected Carpentry Tasks" was conducted to find out the posture adoption and physiological cost of selected carpentry tasks. The sample of the study comprised 45 carpenters from Parbhani town of marathwada region involved in selected carpentry tasks viz cutting with randha machine, cutting with hand tools, finishing with randha machine, finishing with hand tools and fitting. Goniometer was used for measuring the postural angle at lumbar, cervical and elbow region. Physiological cost of selected carpentry tasks was assessed by recording heart rate, energy expenditure and cardiac cost of carpenters while performing the selected tasks. Findings of the study indicated that higher angle of deviation at cervical point was noticed while cutting \& finishing with hand tools, at elbow point was recorded for the task of cutting \& finishing on randha machine and at lumbar point was noticed for the task of fitting. The physiological cost of carpentry task of cutting was more when selected carpenters performed cutting task with hand tools than by randha machine.
\end{abstract}

\section{Introduction}

Carpentry is the art and trade of cutting, working, and joining timber. The term includes both structural timberwork in framing and items such as doors, windows, and staircases (Editor, Britannica 2015). A carpenter is a skilled craftsman who works with timber to construct, install and maintain buildings, furniture and other objects. The carpenters are instrumental in designing, building, installing and repairing structures, fixtures, furniture and other items using wood as a major material. Carpenters use many different hand and power tools to cut and shape wood, plastic, fibre glass or dry wall. Carpentry work is strenuous and require prolonged standing, climbing, bending, and kneeling (Student scholarship.org, 2021)

Posture issues can be created by work methods and improper work places. The poor design of any workshop causes improper postures such as twisting, bending and over reaching. Awkward postures are adopted during some manual handling. These postures increase the discomfort and pain at different parts of the body such as back, neck and shoulders. By providing proper work layout the work condition can be improved (Ghosh 
et al 2010). Carpentry being the most important occupation in interior design and paucity of research on physiological cost of carpentry tasks the study was planned with specific objectives of analyzing posture while carrying out the carpentry tasks and physiological cost of selected carpentry tasks.

\section{Materials and Methods}

Locale of the study: The present study was conducted in Parbhani town of Marathwada region of Maharashtra state. Forty five carpenters who were involved in selected carpentry tasks were observed while doing various carpentry tasks and interviewed personally

Recording heart rate: For measuring the heart rate the polar sport tester heart rate monitor was used. Heart rate was recorded while performing the selected tasks of carpentry. The polar transmitter of the instrument was attached to chest of the subject. The belt length was adjusted as per the measurements of subject so that the fit is snug but not too tight. The heart rate was recorded with the help of watch tied around the wrist of the subject. Then the resting heart rate was recorded in the sitting position without doing any work. Working heart rate was recorded for 15 minute while performing the selected tasks of carpentry. Average peak heart rate $\left(\mathrm{bm}^{-1}\right)$ was noted down during performance of task. Then after completion of the task recovery heart rate was recorded after every minute till a period of normal heart rate.

Postural analysis: Goniometer was used for measuring the postural angle at lumbar, cervical and elbow region. Postural analysis of the respondents at lumbar region, cervical region and elbow region was carried out by calculating angle of deviation while performing selected carpentry activities. Before starting the experiment the natural angle of carpenters at cervical, lumbar and elbow joint region was noted down in static position.

Further the angle of carpenter at cervical, lumbar and elbow region was recorded in active position. The angle of deviation was obtained by subtracting the angle in dynamic position from the natural angle recorded in static position.

\section{Assessment of physiological cost of selected carpentry tasks}

Physiological cost of selected carpentry tasks was assessed by recording heart rate, energy expenditure and cardiac cost of carpenters while performing the selected tasks viz cutting with randhamachine, cutting with hand tools, finishing with randha machine, finishing with hand tools and fitting.

The step by step procedure to calculate physiological cost of carpentry was followed as per formula given by Varghese et al (1994).

Energy expenditure $\left(\mathrm{Kj}_{\mathrm{j}} \mathrm{m}^{-1}\right)=0.159 \mathrm{xAverage}$ working heart rate $\left(\right.$ b. $\left.\mathrm{m}^{-1}\right)-8.72$

Total cardiac cost of work $($ TCCW $)=$ Cardiac Cost of Work (CCW) + Cardiac Cost of Recovery (CCR) X Duration of work

Where,

Cardiac Cost of Work = (Average Working Heart Rate - Average Resting Heart Rate) X Duration of work

Cardiac Cost of Recovery $=$ (Average Recovery Heart Rate - Average Resting Heart Rate) X Duration of work

logical Cost of Work $($ PCW $)=\frac{\text { Total Cardiac Cost of Work (TCCW) }}{\text { Total Time of Work }}$ 


\section{Statistical analysis}

The collected data was analyzed statistically by applying $t$ test and one way analysis of variance.

' $\mathbf{t}$ ' test: ' $\boldsymbol{t}$ ' test was used for assessing the differences in physiological cost of selected carpentry activities carried out manually and with improved tools of carpentry.

Following formula was used to assess ' $t$ ' value Sharma (2005)

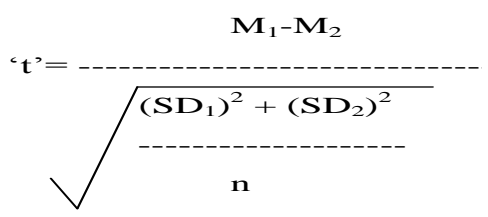

Where,

$\mathrm{M}_{1}=$ Mean value of existing method

$\mathrm{M}_{2}=$ Mean value of improved method

$\mathrm{SD}_{1}=$ Standard deviation of existing method

$\mathrm{SD}_{2}=$ Standard deviation of improved method

$\mathrm{n}=$ Sample size

Analysis of variance: The collected data on physiological cost of selected carpentry tasks was analysed by applying one way analysis of variance technique by using the formula

$F=\frac{\text { MSV }}{\text { MSE }}$

Where,

$\mathrm{MSV}=$ is mean square due to variate effects and

$\mathrm{MSE}=$ is mean square due to error

\section{Results and Discussion}

General information of selected carpenters is given in the table 1. It is observed from the table that majority of the selected carpenters
(68.8\%) were from the age group of 25-35 years followed by the carpenters from age group of $36-45$ years $(31.1 \%)$. It is further noted that majority of the selected carpenters were educated up to secondary level $(60 \%)$ followed by non literate (17.7\%). Majority of the selected carpenters were having monthly income range between Rs. $4000-6000$ per month $(42.2 \%)$ followed by the equal percentage of carpenters (28.9\%) within monthly income range of Rs. 6000 -Rs. 8000 and Rs. 8000 - Rs. 10,000. The working experience of selected carpenters indicated that majority of the selected carpenters were having experience of working in workshop for $1-10$ years $(55.5 \%)$ followed by $11-20$ years $(42.2 \%)$.

The information regarding posture adopted by selected carpenters at carpenter's workshops is presented in table 2. It was noticed that 100 per cent of the selected carpenters were adopting squatting posture while performing measuring and marking tasks and standing posture while performing cutting on randha machine.

The table denotes that 100 per cent of the selected carpenters were adopting sitting posture while sawing, squatting posture while measuring, marking, finishing task with hand tools. Majority of the carpenters were adopting sitting posture while sharpening tools $(93.3 \%)$ and stapling (75.5\%). Equal percentage of carpenters (31.1\%) were adopting sitting posture while designing and repairing furniture. A standing posture while finishing on randha machine was adopted by 91.1 per cent of carpenters. More than fifty per cent of the selected carpenters were adopting bending posture while drilling the wood (51.1\%).Approximately equal percentage of carpenters were adopting postural combo of standing and bending while performing drilling (48.8\%) and designing tasks $(46.6 \%)$. 
Table.1 General information of the selected carpenters

\begin{tabular}{|l|c|c|}
\hline \multicolumn{1}{|c|}{ Attributes } & Frequency & Percentage \\
\hline Age of the carpenters (yrs) & 31 & 68.8 \\
\hline $\mathbf{2 5}$ to 35 & 14 & 31.1 \\
\hline $\mathbf{3 6}$ to 45 & 8 & 17.7 \\
\hline Education of carpenters & 3 & 6.6 \\
\hline Non literate & 27 & 60 \\
\hline Primary education & 7 & 15.5 \\
\hline Secondary education & & \\
\hline Higher secondary education & 19 & 42.2 \\
\hline Monthly Income of the family(Rs) & 13 & 28.9 \\
\hline $\mathbf{4 , 0 0 0}-\mathbf{6 , 0 0 0}$ & 13 & 28.9 \\
\hline $\mathbf{6 , 0 0 0}-\mathbf{8 , 0 0 0}$ & & \\
\hline $\mathbf{8 , 0 0 0}-\mathbf{1 0 , 0 0 0}$ & 18 & 40 \\
\hline Family size (No. of family members) & 22 & 11.1 \\
\hline $\mathbf{1 - 4}$ & 5 & \\
\hline $\mathbf{5 - 8}$ & & \\
\hline$>\mathbf{8}$ & 25 & 42.2 \\
\hline Total experience of working in workshop (yrs) & 19 & 2.2 \\
\hline $\mathbf{1}-\mathbf{1 0}$ & 1 & \\
\hline $\mathbf{1 0}-\mathbf{2 0}$ & & \\
\hline $\mathbf{2 0}-\mathbf{3 0}$ & & \\
\hline
\end{tabular}

Table.2 Posture adopted by the carpenters while performing carpentry tasks

\begin{tabular}{|l|c|c|c|c|c|}
\hline \multirow{2}{*}{$\begin{array}{l}\text { Posture } \rightarrow \\
\text { Carpentry } \\
\text { tasks } \downarrow\end{array}$} & \multicolumn{5}{|c|}{ Frequency and percentage } \\
\cline { 2 - 6 } & Sitting & Standing & $\begin{array}{c}\text { Bending } \\
\text { Cquatting }\end{array}$ & $\begin{array}{c}\text { Combination of } \\
\text { standing \& } \\
\text { bending }\end{array}$ & $\begin{array}{c}\text { Combination of } \\
\text { squatting \& } \\
\text { standing }\end{array}$ \\
\hline Measuring & - & - & - & $45(100)$ & - \\
\hline Marking & - & - & - & $45(100)$ & - \\
\hline Cutting on randha machine & - & $45(100)$ & - & - & - \\
\hline Finishing on randha machine & $4(8.8)$ & $41(91.1)$ & - & - & - \\
\hline Cutting with hand tools & - & - & - & - & - \\
\hline Finishing with hand tools & - & - & - & $45(100)$ & - \\
\hline Drilling & - & - & $23(51.1)$ & - & $22(48.8)$ \\
\hline Sawing & $45(100)$ & - & & - & - \\
\hline Sharpening tools & $42(93.3)$ & - & $3(6.6)$ & - & - \\
\hline Fitting & $10(22.2)$ & $13(28.2)$ & $1(2.2)$ & $1(2.2)$ & - \\
\hline Designing & $14(31.1)$ & $3(6.6)$ & - & $1(2.2)$ & - \\
\hline Repairing & $14(31.1)$ & - & $2(4.4)$ & $2(4.4)$ & - \\
\hline Stapling & $34(75.5)$ & - & $4(8.8)$ & $4(8.8)$ & - \\
\hline
\end{tabular}

Figures in Parenthesis indicate percentages

Table.3 Angle of deviation while performing various carpentry tasks

\begin{tabular}{|c|c|c|c|c|}
\hline Postural points & $\begin{array}{c}\text { Postural point } \\
\text { normal angle } \mathbf{(}^{\mathbf{0}} \text { ) }\end{array}$ & $\begin{array}{c}\text { Fitting task angle } \\
\text { of deviation }\end{array}$ & $\begin{array}{c}\text { Cutting and finishing on } \\
\text { randha machine angle of } \\
\text { deviation }\end{array}$ & $\begin{array}{c}\text { Cutting and finishing with } \\
\text { hand tools angle of deviation }\end{array}$ \\
\hline Cervical joint & $154.5 \pm 16.7$ & $15.8 \pm 1.7$ & $10.7 \pm 2.4$ & $24.8 \pm 4.38$ \\
\hline Elbow joint & $165.4 \pm 7.5$ & $20.4 \pm 3.7$ & $34.7 \pm 5.1$ & $26.8 \pm 0.98$ \\
\hline Lumbar joint & $161.2 \pm 8.1$ & $23.6 \pm 9.04$ & $19.5 \pm 4$ & $20.7 \pm 7.72$ \\
\hline
\end{tabular}


Table.4 Physiological cost of carpentry tasks- finishing with hand tools and randha machine

\begin{tabular}{|c|c|c|c|}
\hline \multirow{2}{*}{$\begin{array}{l}\text { Carpentry tasks } \rightarrow \\
\text { Physiological } \\
\text { Parameters } \downarrow\end{array}$} & \multicolumn{2}{|c|}{ Mean \pm SD } & \multirow[t]{2}{*}{ 't'value } \\
\hline & Hand tool & $\begin{array}{l}\text { Randha } \\
\text { machine }\end{array}$ & \\
\hline Average resting heart rate (b.m $\left.{ }^{-1}\right)$ & $79.56 \pm 1.79$ & $77.48 \pm 1.09$ & $5.4 * *$ \\
\hline Average working heart rate (b.m $\left.{ }^{-1}\right)$ & $107.5 \pm 1.67$ & $105.37 \pm 1.18$ & $5.7 * *$ \\
\hline Average recovery heart rate $\left(\right.$ b.m $\left.{ }^{-1}\right)$ & $87.13 \pm 2.84$ & $86.41 \pm 2.65$ & $1.02 \mathrm{NS}$ \\
\hline Average energy expenditure $\left(\mathrm{kj} . \mathrm{m}^{-1}\right)$ & $8.45 \pm 0.22$ & $7.91 \pm 0.27$ & $10.8 * *$ \\
\hline Average cardiac cost of work (b.m $\left.{ }^{-1}\right)$ & $146.25 \pm 13.24$ & $125.6 \pm 10.97$ & $6.61 * *$ \\
\hline Average cardiac cost of recovery $\left(\mathbf{b} . \mathrm{m}^{-1}\right)$ & $48.25 \pm 15.91$ & $34.25 \pm 13.61$ & $3.67 * *$ \\
\hline Total cardiac cost of work (beats) & $972.5 \pm 106.91$ & $799.5 \pm 97.70$ & $6.67 * *$ \\
\hline Physiological cost of work (b.m $\left.{ }^{-1}\right)$ & $64.79 \pm 7.12$ & $53.23 \pm 6.25$ & $6.72 * *$ \\
\hline
\end{tabular}

**significant at $1 \%$ level of significance NS- Non significant

Table.5 Physiological cost of carpentry tasks- cutting with hand tools and randha machine

\begin{tabular}{|c|c|c|c|}
\hline \multirow{2}{*}{$\begin{array}{l}\text { Carpentry tasks } \rightarrow \\
\text { Physiological } \\
\text { Parameters } \downarrow\end{array}$} & \multicolumn{2}{|c|}{ Mean \pm SD } & \multirow[t]{2}{*}{ 't'value } \\
\hline & Hand tool & $\begin{array}{l}\text { Randha } \\
\text { machine }\end{array}$ & \\
\hline Average resting heart rate (b.m $\left.{ }^{-1}\right)$ & $79.56 \pm 1.79$ & $77.48 \pm 1.09$ & $5.4 * *$ \\
\hline Average working heart rate (b.m $\left.{ }^{-1}\right)$ & $103.03 \pm 0.88$ & $101.43 \pm 0.97$ & $6.95 * *$ \\
\hline Average recovery heart rate (b.m $\left.{ }^{-1}\right)$ & $86.89 \pm 2.99$ & $87.61 \pm 2.74$ & $0.97 \mathrm{NS}$ \\
\hline Average energy expenditure (kj.m $\left.{ }^{-1}\right)$ & $8.24 \pm 0.14$ & $7.47 \pm 0.16$ & $38.5 * *$ \\
\hline Average cardiac cost of work $\left(\mathrm{b} . \mathrm{m}^{-1}\right)$ & $146.57 \pm 9.45$ & $123.9 \pm 7.60$ & $10.5^{* *}$ \\
\hline Average cardiac cost of recovery $\left(b \cdot m^{-1}\right)$ & $47.11 \pm 15.46$ & $52.85 \pm 14.69$ & $1.50 \mathrm{NS}$ \\
\hline Total cardiac cost of work (beats) & $962.42 \pm 112.54$ & $883.75 \pm 80.31$ & $3.11 * *$ \\
\hline Physiological cost of work (b.m $\left.{ }^{-1}\right)$ & $64.52 \pm 6.76$ & $58.88 \pm 5.34$ & $3.63 * *$ \\
\hline
\end{tabular}

$* *$ significant at $1 \%$ level of significance

NS- Non significant

Table.6 Physiological cost of carpentry task- fitting

\begin{tabular}{|c|c|}
\hline Physiological parameters & Recorded value \\
\hline Average resting heart rate $\left(\mathrm{b} . \mathrm{m}^{-1}\right)$ & $79.5 \pm 2.23$ \\
\hline Average working heart rate (b.m $\left.{ }^{-1}\right)$ & $101.9 \pm 0.84$ \\
\hline Average recovery heart rate $\left(\mathrm{b} . \mathrm{m}^{-1}\right)$ & $86.4 \pm 2.59$ \\
\hline Average energy expenditure (kj.m $\left.{ }^{-1}\right)$ & $7.4 \pm 0.13$ \\
\hline Average cardiac cost of Work (b.m $\left.{ }^{-1}\right)$ & $126.1 \pm 11.01$ \\
\hline Total cardiac cost of recovery $\left(\mathrm{b} . \mathrm{m}^{-1}\right)$ & $48.7 \pm 19.50$ \\
\hline Total cardiac cost of Work (beats) & $854.0 \pm 173.64$ \\
\hline Physiological cost of work (b.m $\left.{ }^{-1}\right)$ & $56.9 \pm 11.58$ \\
\hline
\end{tabular}


Table.7 Comparative assessment of physiological cost of selected carpentry tasks

\begin{tabular}{|c|c|c|c|c|c|c|c|c|}
\hline \multirow{2}{*}{$\begin{array}{l}\text { Caepentry tasks } \rightarrow \\
\text { Physiological } \\
\text { parameters } \\
\quad \downarrow\end{array}$} & \multicolumn{5}{|c|}{ Mean \pm SD } & \multirow[t]{2}{*}{ ' $F$ ' value } & \multirow[t]{2}{*}{ SE } & \multirow[t]{2}{*}{ CD } \\
\hline & $\begin{array}{l}\text { Cutting with } \\
\text { hand tools }\end{array}$ & $\begin{array}{l}\text { Cutting on } \\
\text { randha } \\
\text { machine }\end{array}$ & $\begin{array}{c}\text { Finishing } \\
\text { with hand } \\
\text { tools }\end{array}$ & $\begin{array}{l}\text { Finishing } \\
\text { with randha } \\
\text { machine }\end{array}$ & Fitting & & & \\
\hline $\begin{array}{l}\text { Average working } \\
\text { heart rate }\left(\text { b.m }{ }^{-1}\right)\end{array}$ & $103.03 \pm 0.88$ & $101.43 \pm 0.97$ & $107.5 \pm 1.67$ & $105.37 \pm 1.18$ & $101.9 \pm 0.84$ & $126.34 * *$ & 0.23 & 0.65 \\
\hline $\begin{array}{l}\text { Average recovery } \\
\text { heart rate }\left(b^{\prime} \mathbf{m}^{-1}\right)\end{array}$ & $86.89 \pm 2.99$ & $87.61 \pm 2.74$ & $87.13 \pm 2.84$ & $86.41 \pm 2.65$ & $86.4 \pm 2.59$ & 0.93 & NS & NS \\
\hline $\begin{array}{c}\text { Average energy } \\
\text { expenditure (kj.m }\end{array}$ & $8.24 \pm 0.14$ & $7.47 \pm 0.16$ & $8.45 \pm 0.22$ & $7.91 \pm 0.27$ & $7.4 \pm 0.13$ & $202.31 * *$ & 0.03 & 0.08 \\
\hline $\begin{array}{l}\text { Average cardiac } \\
\text { cost of work }\left(\text { b.m }{ }^{-1}\right)\end{array}$ & $146.57 \pm 9.45$ & $123.9 \pm 7.60$ & $146.25 \pm 13.24$ & $125.6 \pm 10.97$ & $126.1 \pm 11.01$ & $45.26^{* *}$ & 1.72 & 4.78 \\
\hline $\begin{array}{l}\text { Average cardiac } \\
\text { cost of recovery } \\
\left(\text { b. } \mathbf{m}^{-1}\right)\end{array}$ & $47.11 \pm 15.46$ & $52.85 \pm 14.69$ & $48.25 \pm 15.91$ & $34.25 \pm 13.61$ & $48.7 \pm 19.50$ & $5.82 * *$ & 2.91 & 8.08 \\
\hline $\begin{array}{l}\text { Total cardiac cost of } \\
\text { work (beats) }\end{array}$ & $962.42 \pm 112.54$ & $883.75 \pm 80.31$ & $972.5 \pm 106.91$ & $799.5 \pm 97.70$ & $854.0 \pm 173.6$ & $11.82 * *$ & 21.33 & 59.03 \\
\hline $\begin{array}{l}\text { Physiological cost of } \\
\text { work }\left(\mathrm{b}^{-1}\right)\end{array}$ & $64.52 \pm 6.76$ & $58.88 \pm 5.34$ & $64.79 \pm 7.12$ & $53.23 \pm 6.25$ & $56.9 \pm 11.58$ & $12.84 * *$ & 1.39 & 3.84 \\
\hline
\end{tabular}

**Significant at 1 per cent level NS Non significant 
Fitting and repairing was carried out in standing and bending combination of posture by 37.7 and 33.3 per cent of carpenters respectively. Combination of squatting and standing was observed among 26.6 per cent and 13.3 per cent of the selected carpenters while performing repairing and designing respectively.

Deviation of body at cervical, elbow and lumbar point while performing selected carpentry tasks from natural body angle was noted down and the angle of deviation is presented in table 3 . It is clear from the table that the angle of deviation at cervical point while performing carpentry task of cutting and finishing was maximum $\left(24.8^{\circ}\right)$ followed by fitting task $\left(15.8^{\circ}\right)$. Angle of deviation at elbow joint was more while performing cutting \& finishing task on randha machine $\left(34.7^{\circ}\right)$ followed by task of cutting \& finishing with hand tools $\left(26.8^{\circ}\right)$. Angle of deviation at lumbar point was higher while performing the task of fitting $\left(23.6^{\circ}\right)$ followed by cutting $\&$ finishing with hand tools $\left(20.7^{\circ}\right)$ and cutting and finishing task on randha machine $\left(19.5^{\circ}\right)$.

Ergonomic evaluation of carpentry task was carried out to know the physiological workload of the selected carpenters while performing finishing task with hand tools and randha machine and is presented in table 4 . It is clear from the table that values of physiological parameters of selected carpenters such as average working heart rate $\left(105.37\right.$ b.m $\left.{ }^{-1}\right)$, average recovery heart rate (86.41 b.m $\left.{ }^{-1}\right)$, average energy expenditure $\left(7.91 \mathrm{kj} \cdot \mathrm{m}^{-1}\right)$, average cardiac cost of work $\left(125.6\right.$ b. $\left.\mathrm{m}^{-1}\right)$, average cardiac cost of recovery $\left(34.25\right.$ b.m $\left.\mathrm{m}^{-1}\right)$, total cost of work (799.5 beats) and physiological cost of work

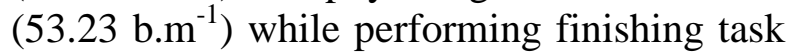
of carpentry with randha machine were lower than the finishing task of carpentry when carried out by using hand tools. Statistical analysis with ' $\mathrm{t}$ ' value indicated significantly lower values $(\mathrm{P} \leq 0.01)$ for all the physiological parameters except for average recovery heart rate when the task was performed by using randha machine.

The information regarding physiological cost of carpentry task of cutting with hand tools and randha machine is presented in table 5. It is evident from the table that the recorded values for average working heart rate (103 b. $\left.\mathrm{m}^{-1}\right)$, average recovery heart rate $\left(86.8\right.$ b.m $\mathrm{m}^{-}$ $\left.{ }^{1}\right)$, average energy expenditure $\left(8.2 \mathrm{kj} \cdot \mathrm{m}^{-1}\right)$, average cardiac cost of work (146.5 b.m $\left.\mathrm{m}^{-1}\right)$,

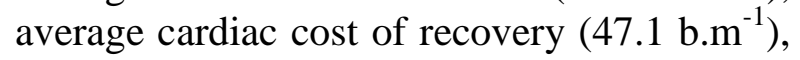
total cardiac cost of work (962.4 beats) and physiological cost of work $\left(64.5 \mathrm{b.m}^{-1}\right)$ of selected carpenters were observed to be higher when the task of cutting was performed with hand tools than the values recorded after performing cutting task on randha machine. Statistical analysis with ' $t$ ' manifested significant reduction in average working heart rate $(\mathrm{t}=6.95 * *)$, average energy expenditure $\left(\mathrm{t}=38.5^{* *}\right)$, average cardiac cost of work $\left(\mathrm{t}=10.5^{* *}\right)$, physiological cost of work $\left(\mathrm{t}=3.63^{* *}\right)$ and total cardiac cost of work $\left(\mathrm{t}=3.11^{* *}\right)$ of selected carpenters when the carpentry tasks of cutting was carried out on randha machine.

The information regarding physiological cost of fitting task in carpentry is presented in table 6. It is notified from the table that the average working heart rate of carpentry tasks fitting was 101.9 b.m ${ }^{-1}$, while average recovery heart rate, average energy expenditure, average cardiac cost of work and average cardiac cost of recovery of fitting task were 86.4 b.m ${ }^{-1}, 7.4$ kj.m ${ }^{-1}, 126.1$ b.m ${ }^{-1}$ and $48.7 \mathrm{~b} . \mathrm{m}^{-1}$ respectively. Total cardiac cost of work and physiological cost of fitting task was noted to be 854 beatsand 56.9 b.m ${ }^{-1}$ respectively.

Comparative assessment of physiological cost 
of selected carpentry tasks such as fitting, finishing with hand tools, finishing on randha machine, cutting with hand tools and cutting on randha machine is presented in table 7. It is clear from the table that the significant variation was noticed in average working heart rate $(\mathrm{F}=126.34 * *)$, average energy expenditure $\left(\mathrm{F}=202.31^{* *}\right)$, average cardiac cost of work $\left(\mathrm{F}=45.26^{* *}\right)$ average cardiac cost of recovery $(\mathrm{F}=5.82 * *)$, total cardiac cost of work $(\mathrm{F}=11.82 * *)$ and physiological cost of work $(\mathrm{F}=12.84 * *)$ while performing selected carpentry tasks of cutting with hand tool and randha machine, finishing with hand tools and randha machine and fitting.

Significantly highest value for average working heart rate (107.5), average energy expenditure (8.45), total cardiac cost of work (972.5) and physiological cost of work (64.79) were recorded while performing finishing task with hand tools. The maximum average cardiac cost of work (146.57) was noticed while performing the carpentry task of cutting when performed with hand tools, whereas the average cardiac cost of recovery (52.85) was found to be more when the cutting task performed with randha machine.

On the whole it can be concluded that majority of the carpenters adopted sitting, standing, squatting and combination of squatting \& standing posture while performing majority of the carpentry tasks. The physiological cost of the finishing task in carpentry was found to be higher when performed with hand tools. Use of randha machine for finishing task can reduce the physiological cost of carpentry taskfinishing.

\section{References}

Encyclopædia Britannica, 2015 https://www.britannica.com/technology/ carpentry. Access date 5-1-2021

https://studentscholarships.org/salary/427/car penters.phpAccess date 5-1-2021

Ghosh T., Das B. and Gangopadhyay S. 2010. Work-related Musculoskeletal Disorder: An Occupational Disorder of the Goldsmiths in India.Indian J Community Med, 35(2):321-5

Sharma H.L. 2005 Basic Statistical Methods with Applications.Agrotech.Publishing Academy, Udaipur.Pp 143, 262,267

Varghese M.A, Saha P.N. and Atreya N. 1994. A rapid appraisal of occupational work load from a modified scale perceived exertion.Ergonomic 37(3):485-497

\section{How to cite this article:}

Madhuri Kulkarni and Priyanka Khakare. 2021. Assessment Physiological Cost of Selected Carpentry Tasks. Int.J.Curr.Microbiol.App.Sci. 10(01): 2687-2694. doi: https://doi.org/10.20546/ijcmas.2021.1001.312 